\title{
Choose Idaho Presentation
}

\section{June 2021}

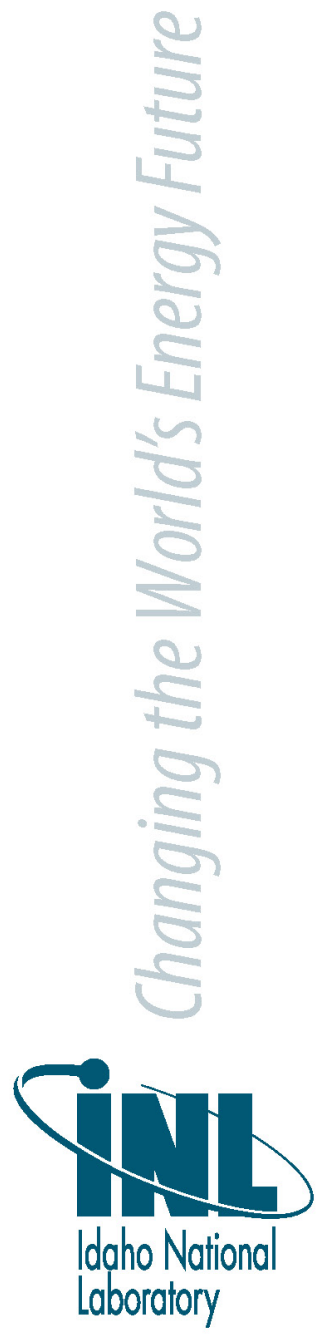

Amy Rene Lientz, Hope Marie Morrow 


\section{DISCLAIMER}

This information was prepared as an account of work sponsored by an agency of the U.S. Government. Neither the U.S. Government nor any agency thereof, nor any of their employees, makes any warranty, expressed or implied, or assumes any legal liability or responsibility for the accuracy, completeness, or usefulness, of any information, apparatus, product, or process disclosed, or represents that its use would not infringe privately owned rights. References herein to any specific commercial product, process, or service by trade name, trade mark, manufacturer, or otherwise, does not necessarily constitute or imply its endorsement, recommendation, or favoring by the U.S. Government or any agency thereof. The views and opinions of authors expressed herein do not necessarily state or reflect those of the U.S. Government or any agency thereof. 


\title{
Choose Idaho Presentation
}

\author{
Amy Rene Lientz, Hope Marie Morrow
}

June 2021

\section{Idaho National Laboratory Idaho Falls, Idaho 83415}

\author{
http://www.inl.gov
}

\author{
Prepared for the \\ U.S. Department of Energy \\ Under DOE Idaho Operations Office \\ Contract DE-AC07-05ID14517
}




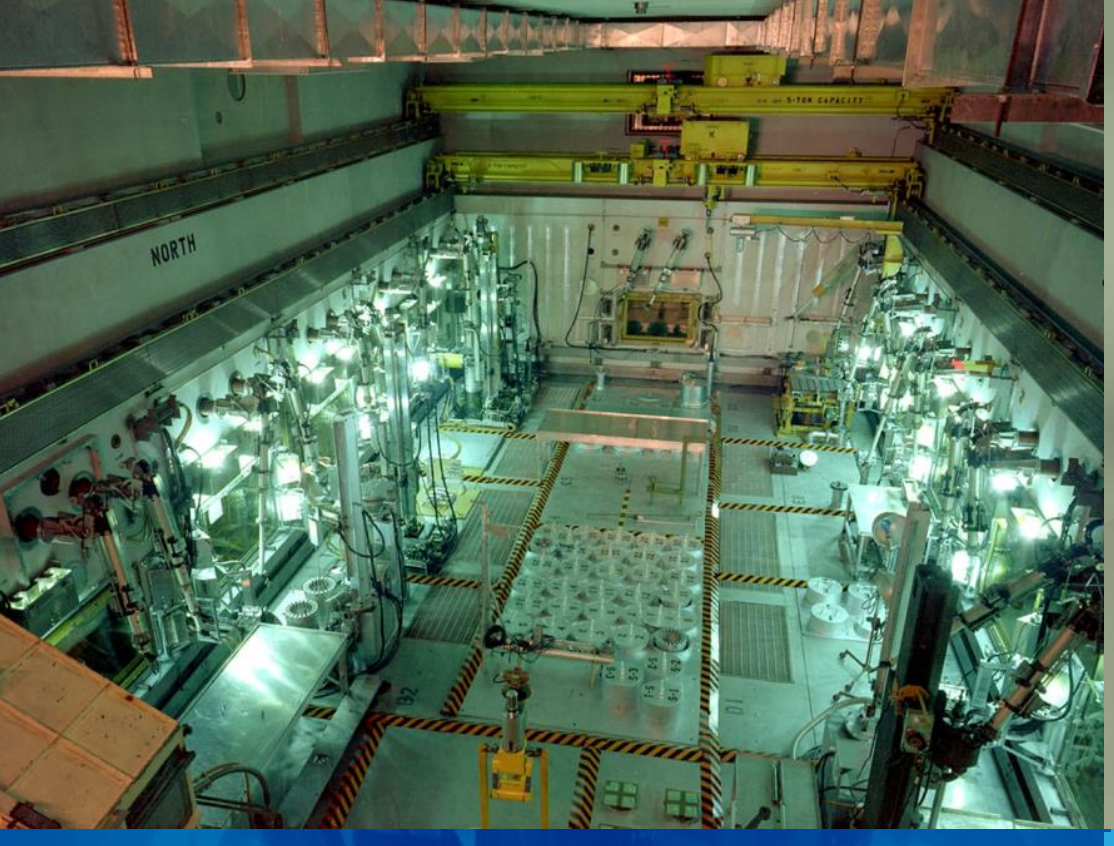

Amy Lientz

Director

Supply Chain, Ehergy

Programs

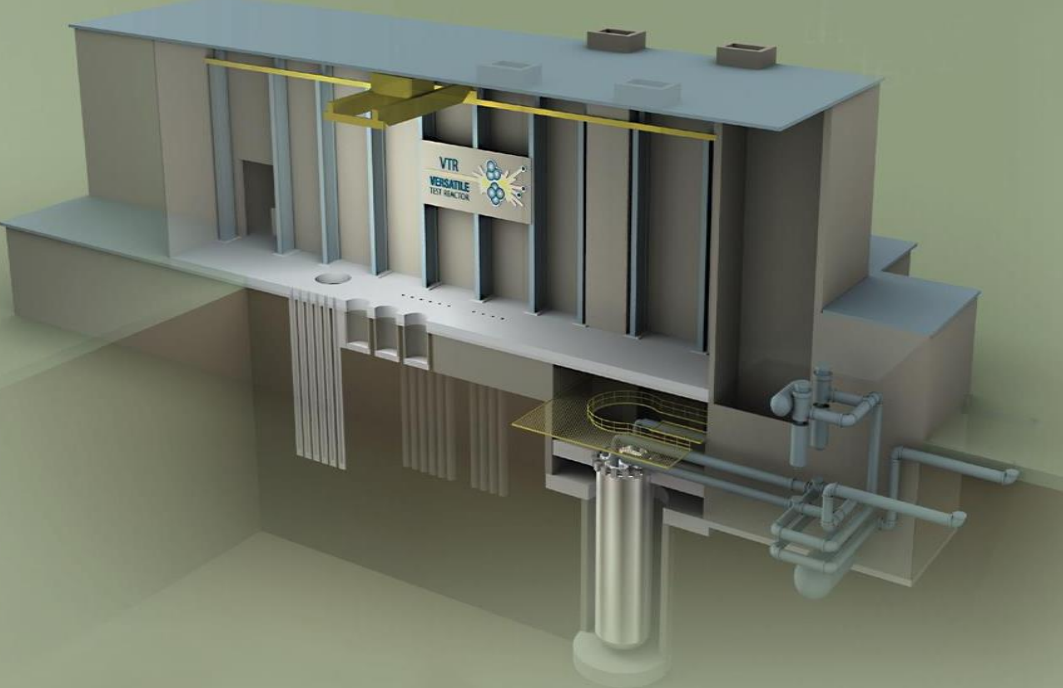

Choose Idaho-

Socioeconomic and Industry

Site Selection Information

May 13, 2021

XLI Idaho National laboratory 


\section{INL Available Information}

- Socioeconomic Information

- Economic Impact

- Workforce Availability

- Education

- Supply Chain Availability

- Community Support

- Watchdog and Advisory Organizations

- Additional Resources

- Summary 


\section{Socioeconomics Population and Housing}

- Idaho is one of the fastest growing states in the nation.

- Population growth in the region between 2000 and 2018 was slightly lower than the State average, with growth rates for the region and State at 7.4 percent and 11.9 percent, respectively.

\begin{tabular}{|c|c|c|c|c|c|}
\hline \multirow[b]{2}{*}{ County } & \multicolumn{4}{|c|}{ Year } & \multirow{2}{*}{$\begin{array}{c}\text { Projected } \\
\text { Population } \\
2050\end{array}$} \\
\hline & 2000 & 2010 & 2018 & $\begin{array}{l}\text { Population Change } \\
2010-2018 \\
\text { (percent) }\end{array}$ & \\
\hline Bannock & 78,604 & 82,839 & 87,138 & 5.2 & 105,263 \\
\hline Bingham & 41,735 & 45,607 & 46,236 & 1.4 & 48,825 \\
\hline Bonneville & 82,522 & 104,234 & 116,854 & 12 & 172,944 \\
\hline Butte & 2,899 & 2,891 & 2,611 & -9.7 & 1,598 \\
\hline Clark & 1,092 & 982 & 852 & -13.2 & 402 \\
\hline Jefferson & 19,155 & 26,140 & 29,439 & 12.6 & 44,276 \\
\hline Madison & 27,467 & 37,536 & 39,304 & 4.7 & 46,693 \\
\hline 7.County ROI & 250,365 & 300,229 & 322,434 & 7.4 & 420,001 \\
\hline Idaho & $1,293,953$ & $1,567,582$ & $1,754,208$ & 11.9 & $2,371,689$ \\
\hline
\end{tabular}

$\mathrm{RO}=$ = region of influence

Source: Census 2019a, 2019b, 2019c; Idaho Department of Labor 2020 


\section{Socioeconomics}

Eastern Idaho Population by County (ref: Census 2019, Dept of Labor) (Bubble Size $=$ Population)

$25 \%$

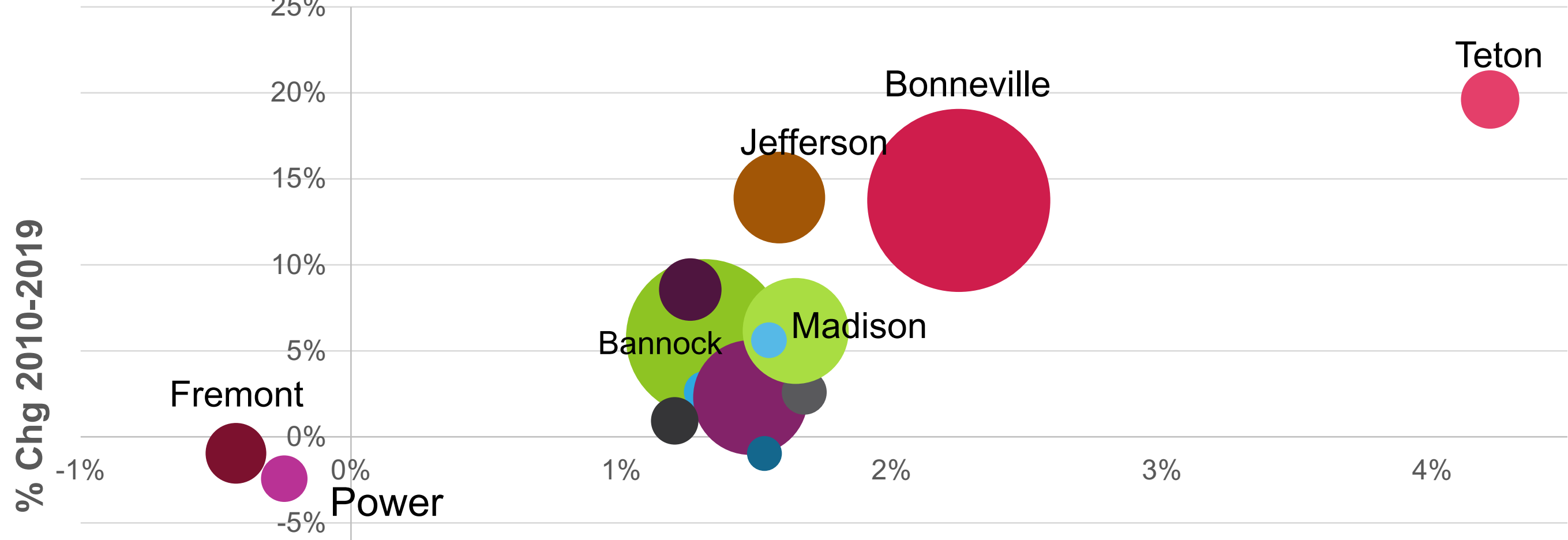

Butte

Clark

$-10 \%$

○
- Bannock

- Bear Lake

- Bingham

- Bonneville

- Butte

- Caribou

- Clark

- Custer

- Franklin

- Fremont

- Jefferson

- Lemhi

- Madison

- Oneida

- Power

- Teton

\% Chg 2018-2019 
Socioeconomics INL Employment

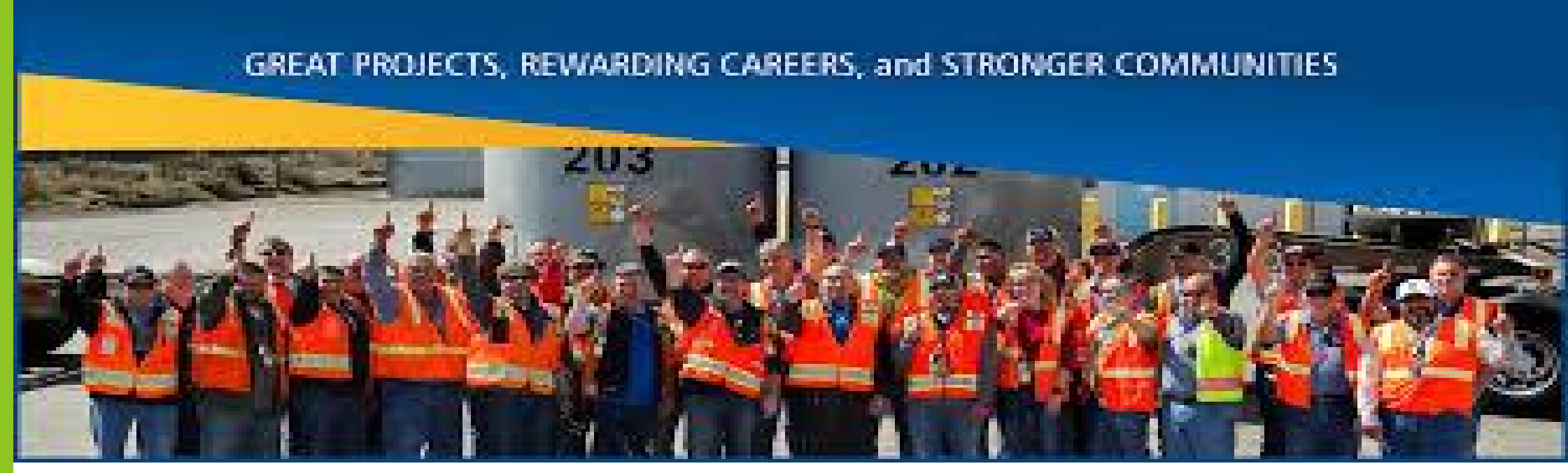

- The prime contractors at the INL Site include BEA, the management and operations contractor for the INL Site, and Fluor Idaho, which manages ongoing cleanup operations under the ICP Core and operates the Advanced Mixed Waste Treatment Project. Also the Department of Energy and the Naval Reactors Facility have full time employees.

- In fiscal year (FY) 2018, the INL Site accounted for nearly 12,000 jobs $(11,789)$, including direct, indirect, and induced employment (INL 2019d), where direct jobs include those employed directly at the INL Site, indirect jobs include jobs relating to suppliers (provide materials and supplies), and induced jobs include jobs in goods and services where workers spend their money.

- INL is the $7^{\text {th }}$ largest employer in the state.

- The largest percentage (60.4 percent) resides within Bonneville County. 


\section{Economic Impact (ref: Idaho Department of Labor) Change in Real GDP by County}

(Bubble Size $=$ Real GDP in Thousands)

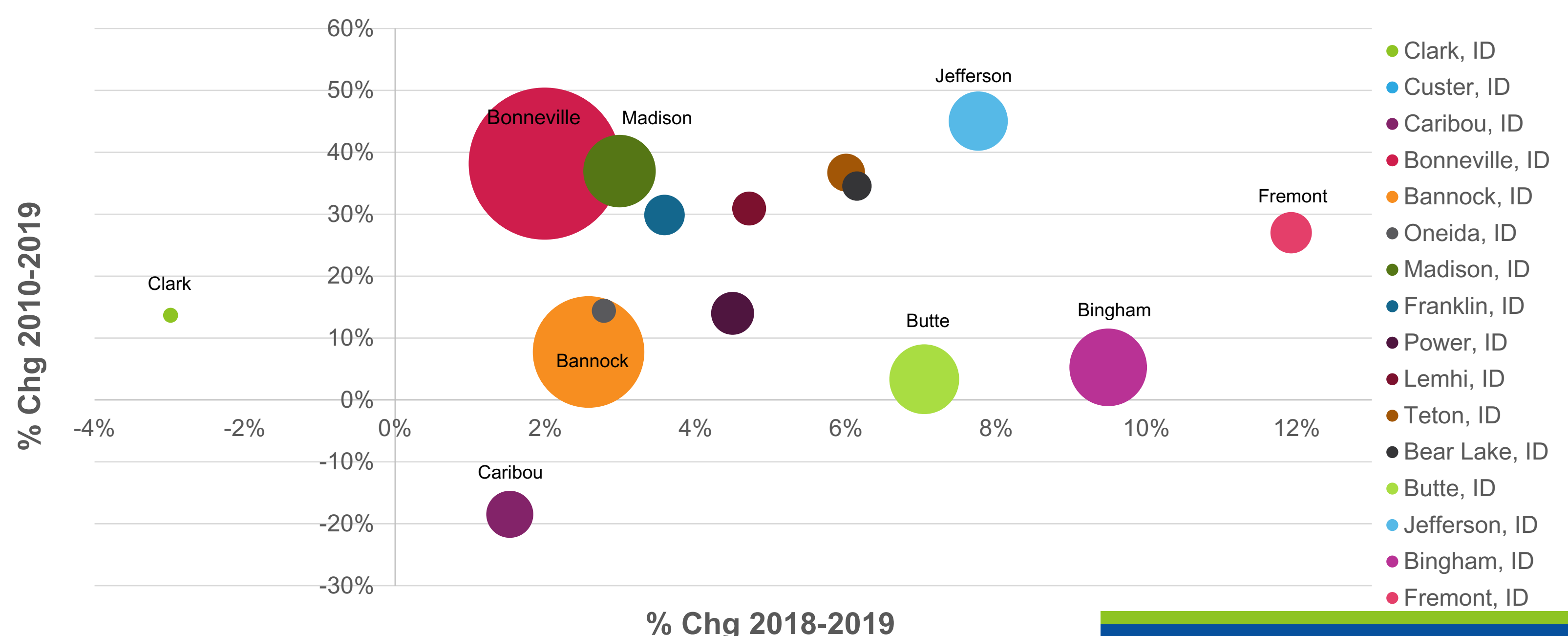




\section{Economic Impact (ref: Idaho Department of Labor)}

Per Capita Personal Income by County
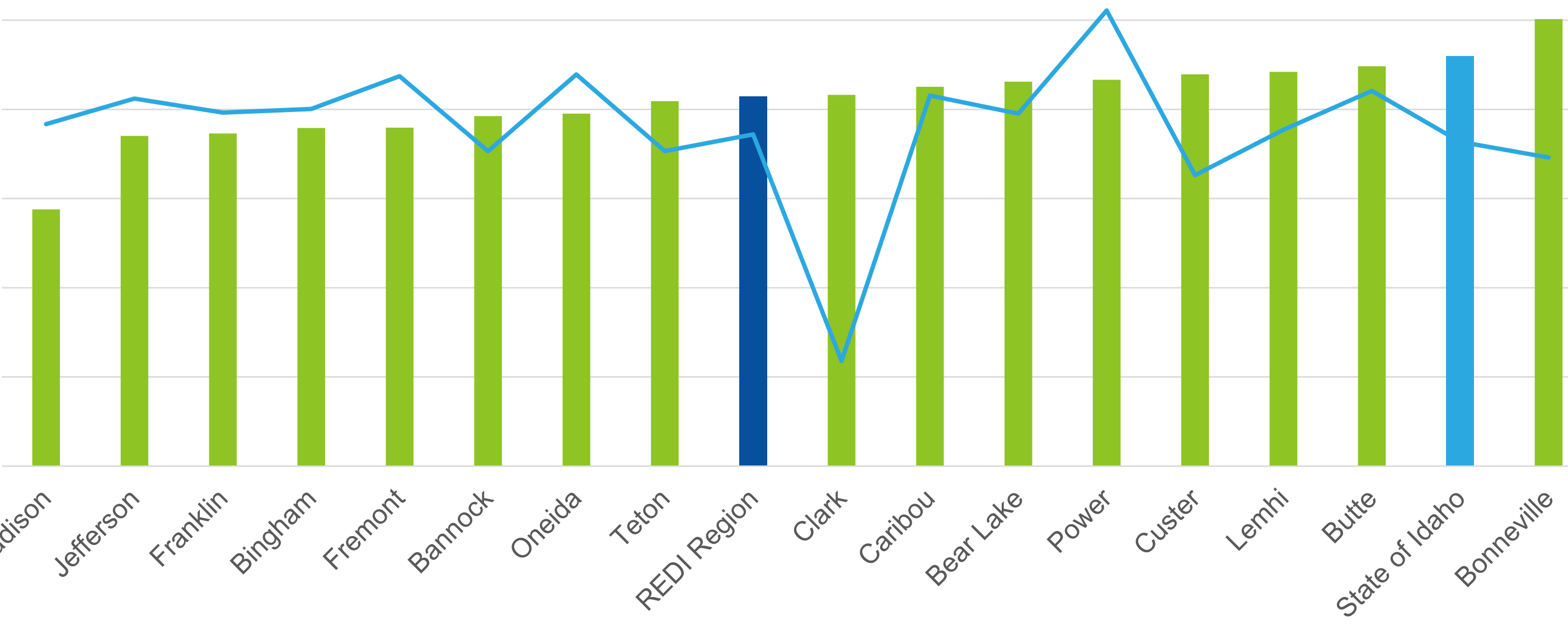


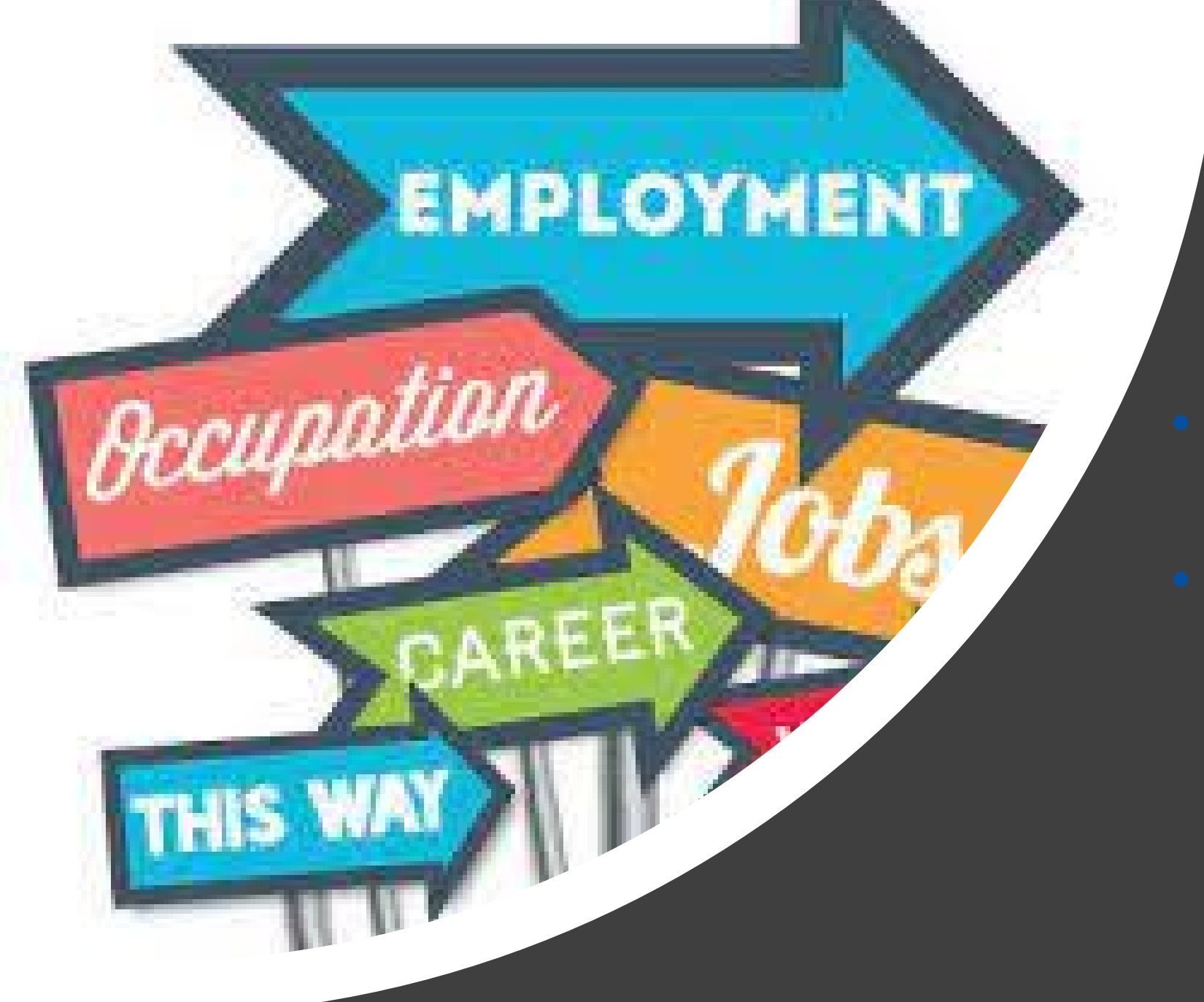

INL Economic Impact (FY2020)

INL is the $7^{\text {th }}$ Largest private employer in Idaho and $10^{\text {th }}$ Largest employer overall

Eastern Idaho INL Statistics

\$147.1 million spent at small businesses in eastern Idaho

250 eastern Idaho business partners $\$ 263,000$ in STEM grants and scholarships

$\$ 104,000$ average INL employee salary 


\section{Economic Impact}

INL Projections

$$
\begin{aligned}
& \text { (5) } \$ 3.5 \\
& \text { 을 } \$ 3.0 \\
& \$ 2.5 \\
& \$ 2.0 \\
& \$ 1.5 \\
& \$ 1.0 \\
& \$ 0.5 \\
& \$ 0.0
\end{aligned}
$$
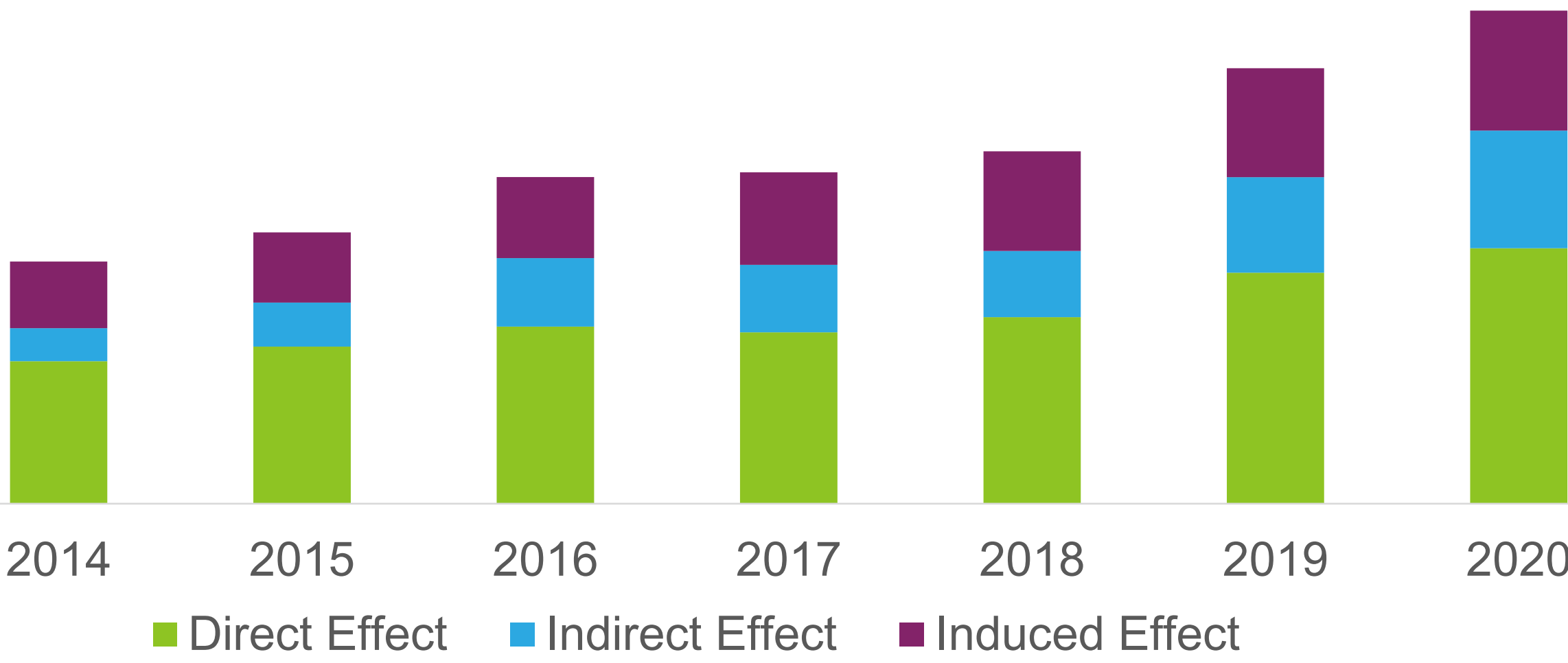

2019

2020 


\section{INL Total Output Economic Impact}

$$
\begin{array}{r}
\$ 3.5 \\
\stackrel{0}{\text { 을 }} \$ 3.0 \\
\overline{\overline{\bar{m}}} \$ 2.5 \\
\$ 2.0 \\
\$ 1.5 \\
\$ 1.0 \\
\$ 0.5 \\
\$ 0.0
\end{array}
$$
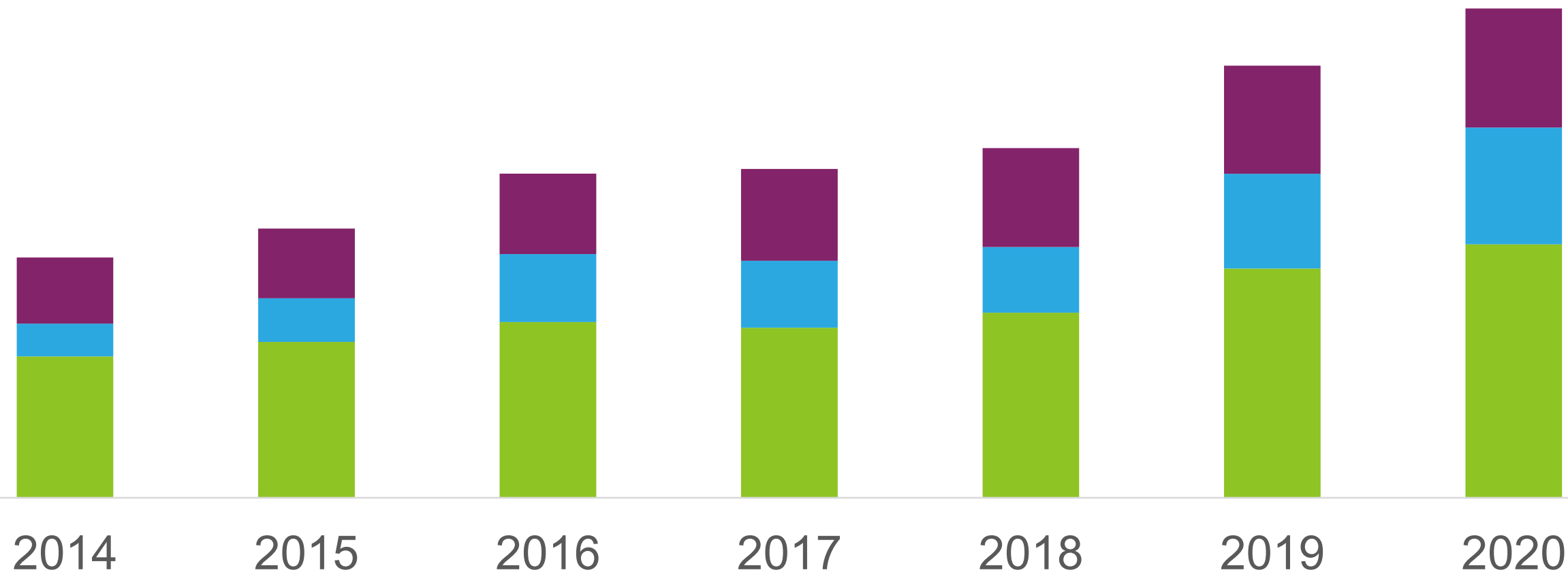

2018

2019

2020

Direct Effect

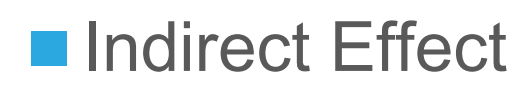

- Induced Effect 


\section{INL Employment Impact}

(Idaho Jobs Created/Sustained)

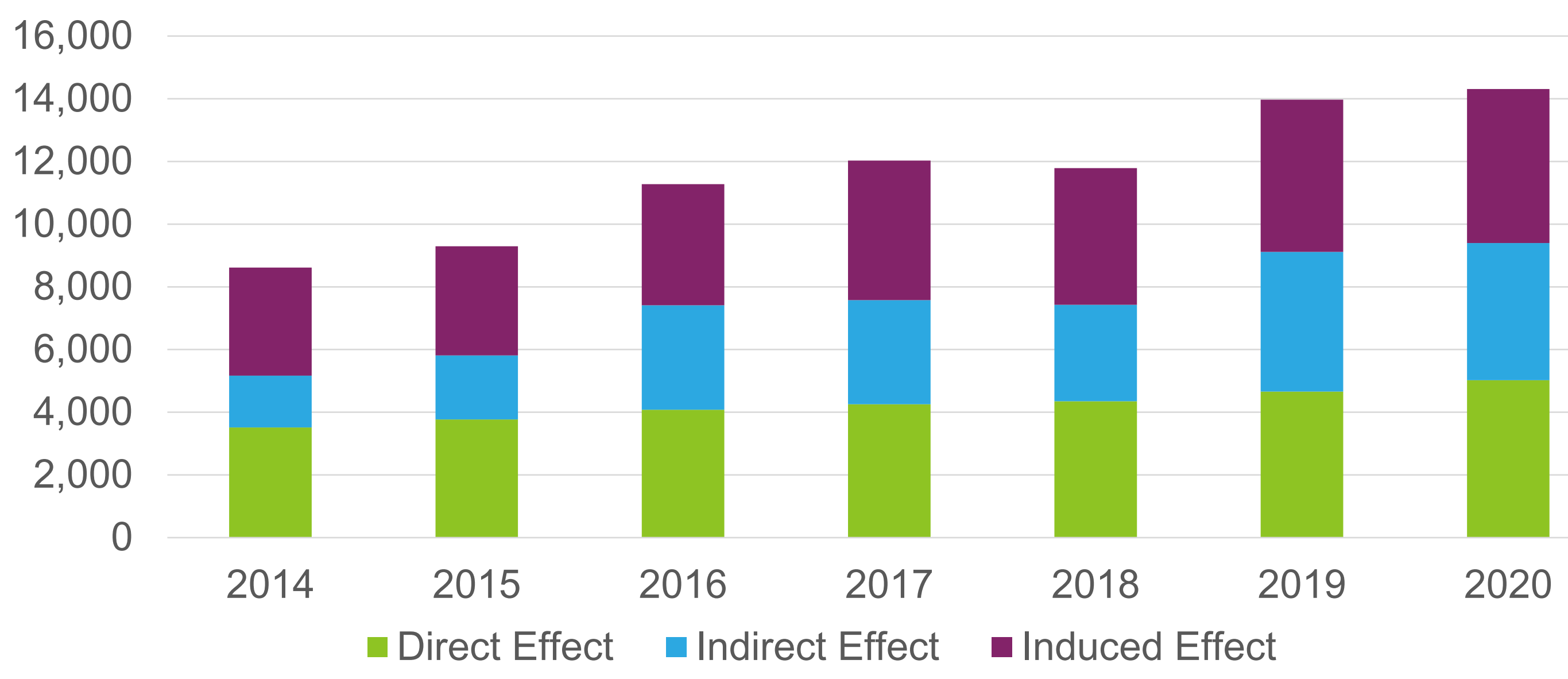




\section{Ideal Timeline and Workforce Estimates/New Nuclear Builds at INL}

Reactor Builds- Temporary Construction and Full Time Workforce

Projections

1200

1000

800

600

400

200

0

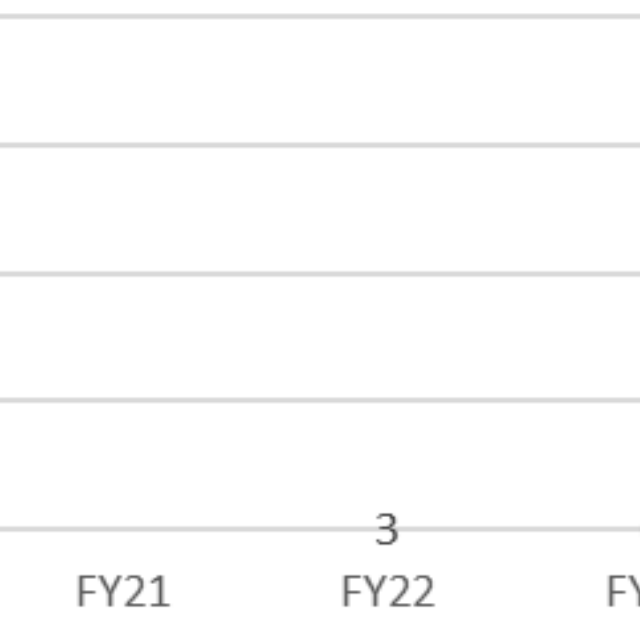

- VTR-FT

vTR-Build

- TerraPower-FT

- TerraPower-Build

nuScale-FT

NuScale- Build 


\section{Workforce Availability (ref: Idaho Department of Labor)} Idaho Unemployment Claimant Occupations

Farming, Fishing \& Forestry

Bld \& Grd Cleaning \& Maint

Healthcare Pract \& Tech

Healthcare Support

Construction \& Extraction

Production

Tansp. \& Mat Moving

Management

Sales

Office \& Admin Support

Food Prep \& Related
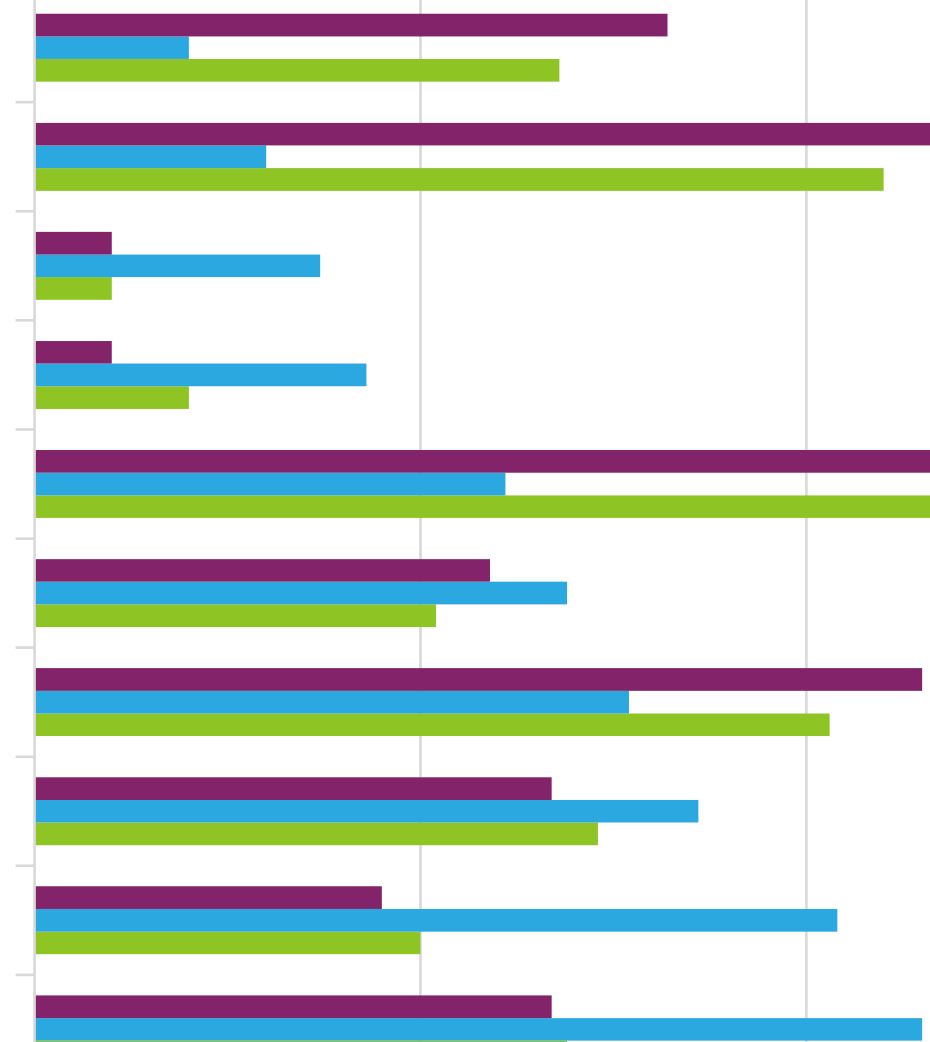

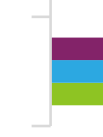

$0 \%$

$5 \%$

$10 \%$

$15 \%$

- Jan-20

- Jul-20

- Jan-21 


\section{Workforce Availability (ref: Idaho Department of Labor)}

Idaho Unemployment Claimant Industries

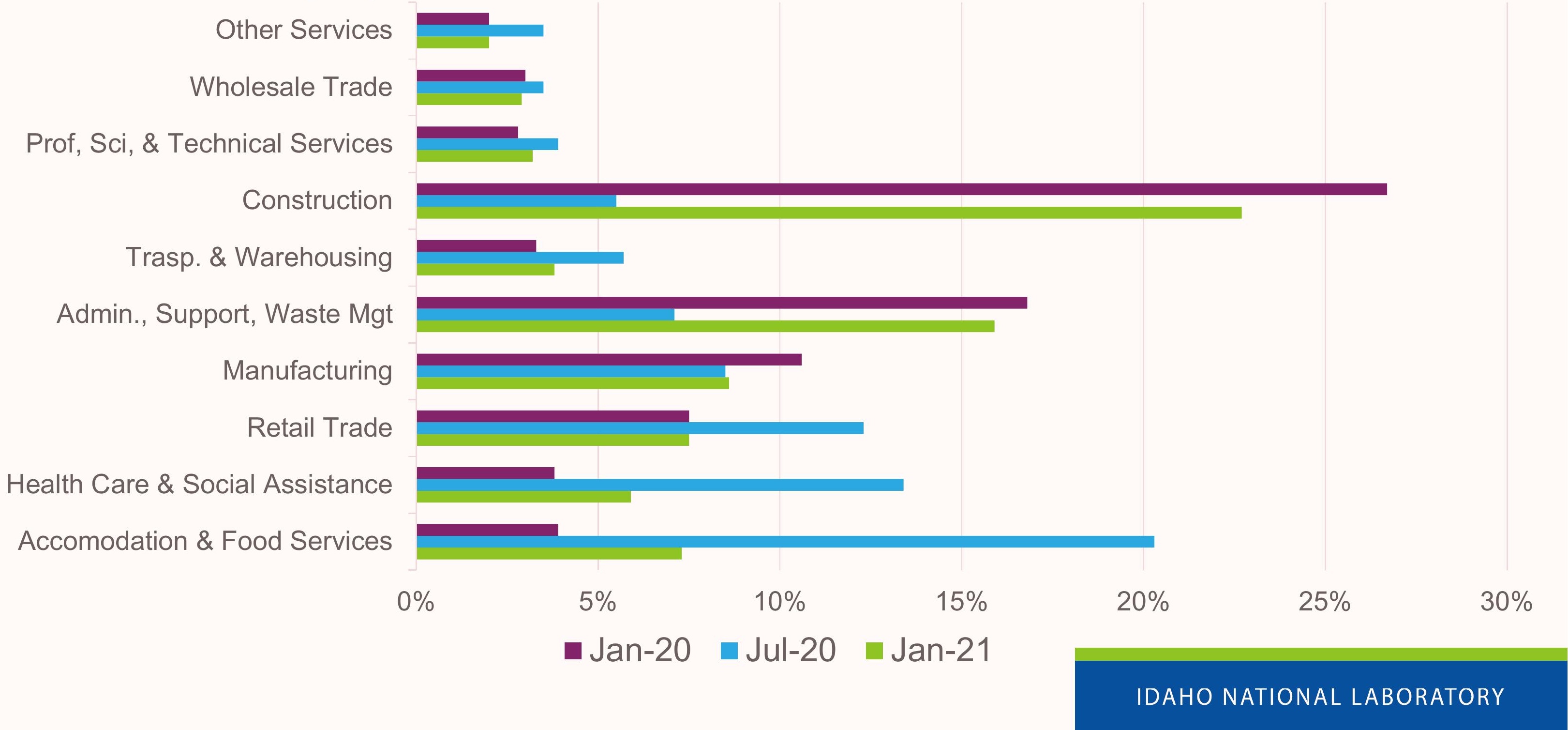




\section{Energy Industry Workforce Education in Idaho}

- 50,829 workers employed in the energy industry

- 10 Colleges and University with Energy Courses, Certifications and Degrees

- 60 Energy related degree programs 


\section{Education \\ Key Energy Education Programs}

- The Center for Advanced Energy Studies (CAES) brings together Idaho and regional universities to conduct research, educate the next generation of scientists and engineers, and enable partnerships with industry.

- University of Idaho, with campuses across the state, is home to engineering programs in power systems, nuclear, electrical, and more.

- Idaho State University created the Energy Systems Technology and Education Center to support growing needs in energy maintenance.

- The Micron School of Materials Science and Engineering is an integral part of Boise State University's Materials Science and Engineering program.

- Idaho colleges in every region offer programs to build skills in technology, operations and maintenance, and provide worker training to keep these skills relevant.

- Northwest Lineman College's apprenticeship program prepares its students to lead the way in construction, maintenance, and operation of the electrical grid. 


\section{Supply Chain Availability for Energy Companies}

- From manufacturing to professional and engineering services, ldaho has an inventory of thousands of energy industry suppliers distributed throughout the state, making it possible to access critical supply chain resources quickly.

- Eastern Idaho is home to national recognized nuclear product manufactures and partnerships with Utah's defense manufacturing community providing important access to more suppliers.

- Idaho is home to successful energy startups and innovation programs to help suppliers expand into new products 


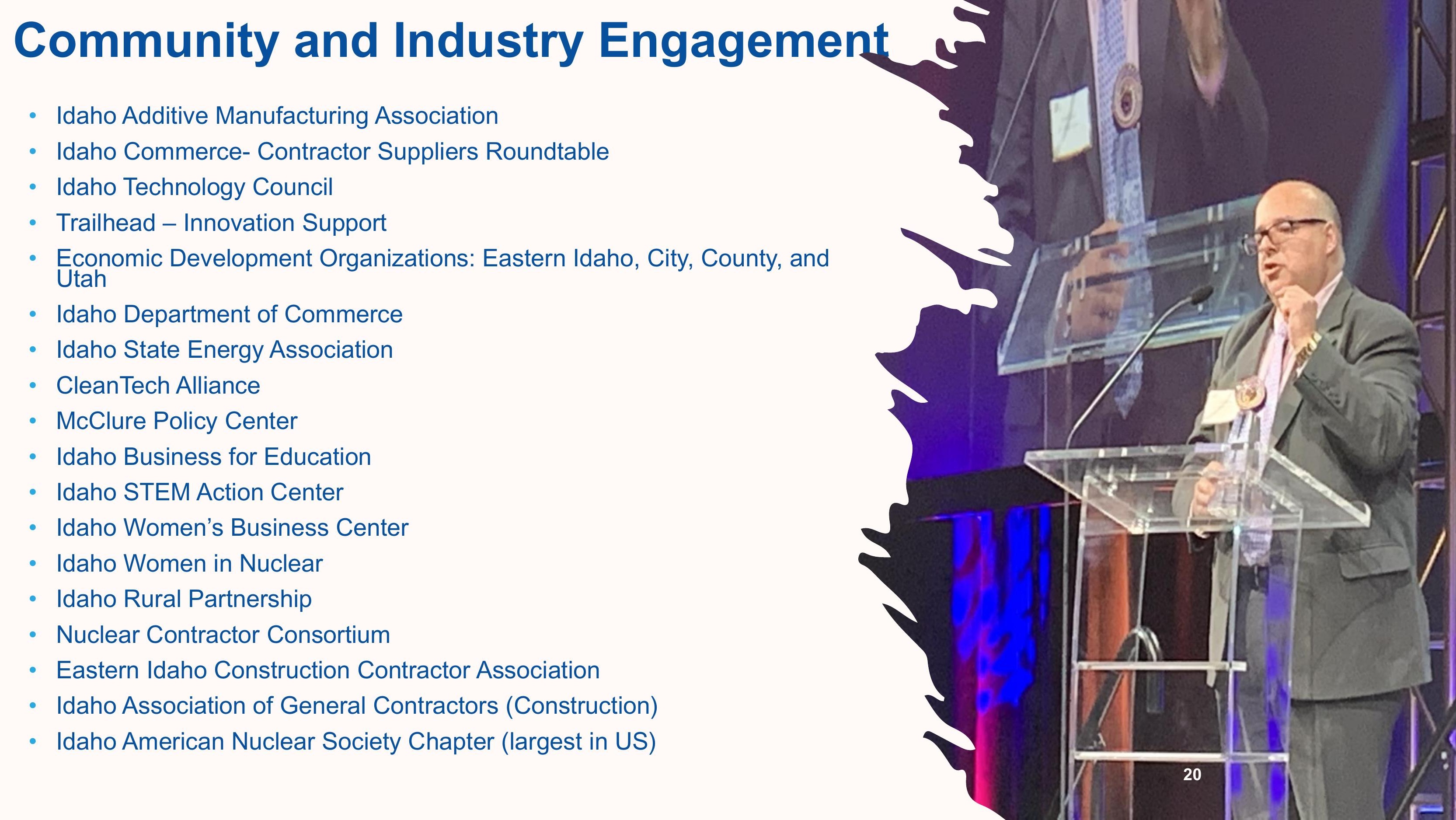




\section{Idaho Nuclear Watchdog and Advisory Organizations}

- Snake River Alliance: Vision "We envision an Idaho where our people and our environment are free from the threat of nuclear waste and contamination, and our communities are healthy, strong, and prosperous because of our reliance on clean and renewable energy." https://snakeriveralliance.org/

- Idaho Citizens Advisory Board: The Idaho Cleanup Project CAB is a federally appointed citizens' panel that provides independent advice and recommendations to the Office of Assistant Secretary, and designees, for the U.S. DOE Environmental

Management Program. https://www.energy.gov/em/icpcab/idaho-cleanup-projectcitizens-advisory-board-icp-cab

- Idaho Governors Leadership in Nuclear Energy Commission: The LINE Commission makes recommendations to the Governor on policies and actions of the State of Idaho to support and enhance the long-term viability and mission of the Idaho National Laboratory and other nuclear industries in Idaho. https://line.idaho.gov/ 


\section{Additional Resources}

- U.S. News identified Idaho as the least regulated state in the country. In $2019,75 \%$ of regulatory rules in Idaho were cut or simplified, making government less burdensome on taxpayers and business

- In 2018, Idaho was ranked the third best state for business friendliness by CNBC. Qualifying companies reap the benefits of a variety of state-sponsored tax incentives, property tax exemptions and workforce training grants

- For More information contact the Site Selectors at INL or the Idaho Department of Commerce:

- https://inl.gov/inl-siting/

- https://commerce.idaho.gov/site-selection/

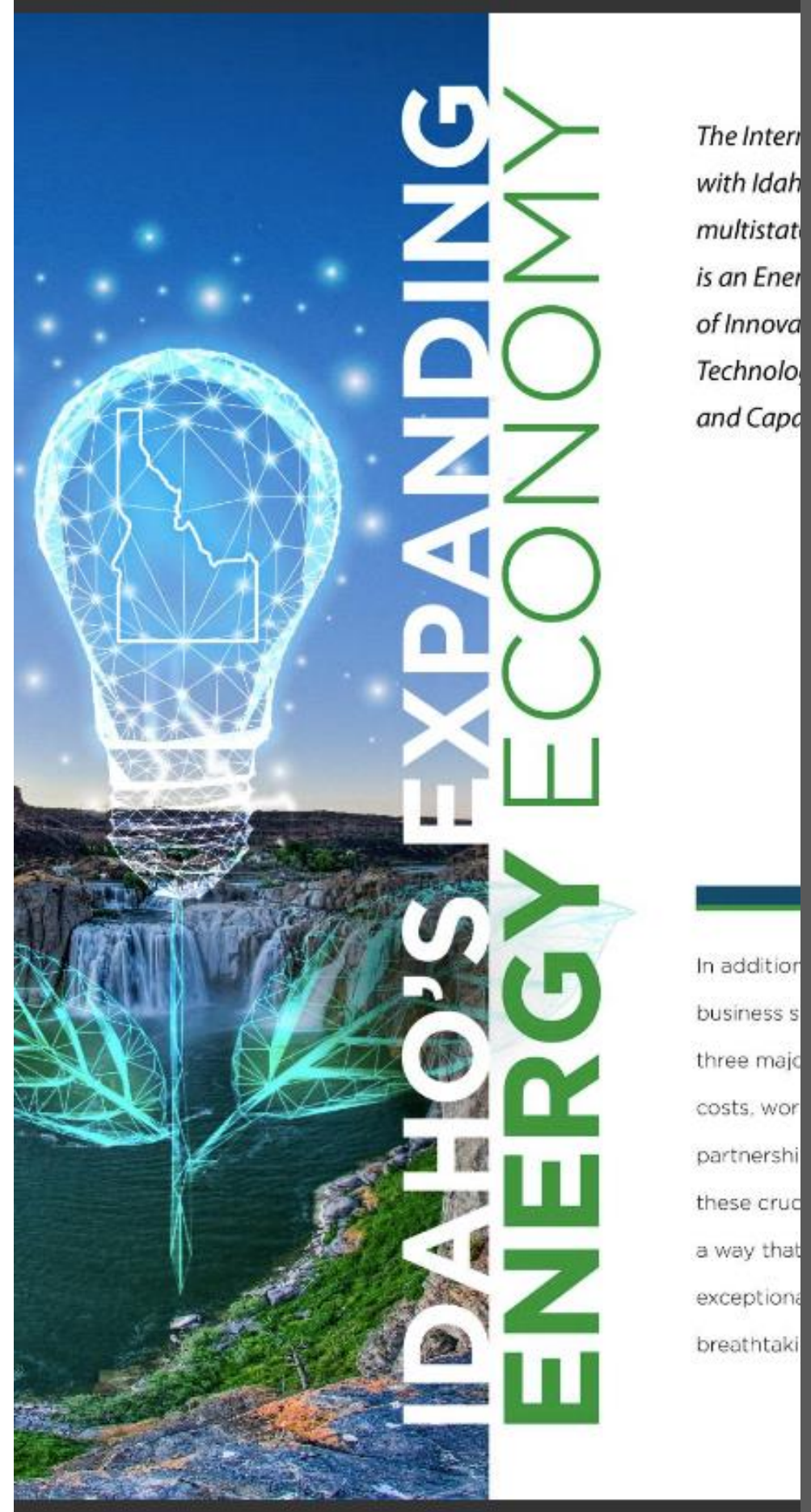




\section{Choose Idaho- Where Energy Industries Succeed}

\section{The (Low) Cost of Business}

$\checkmark$ Idaho is nationally recognized as the least regulated state in the nation

$\checkmark$ Grants and incentives available to support new business interests

$\checkmark$ Idaho's nimbleness, creative partnerships, and committed leadership increases speed to delivery

\section{A Ready, Energy Skilled Workforce}

$\checkmark$ Nearly 60,000 people in Idaho work in the energy business

$\checkmark$ Idaho offers over 60 degrees/certifications and graduates 30,000 students/year

\section{Statewide Innovation and Research Capabilities}

$\checkmark$ World expertise in talent, equipment, capability to lead the world in carbon-free energy innovation

\section{Robust Energy Supply, business support, and Infrastructure}

$\checkmark$ With easy access to vast natural resources, Idaho can claim that over $80 \%$ of its energy is carbon-free.

$\checkmark$ Gateway West, crosses Idaho's geography and will allow for new energy sources to come online in the future.

$\checkmark$ The state is home to a diverse array of businesses in manufacturing, cybersecurity, engineering, materials, etc. 